\author{
白木まさ子, 岩㟝 奈 穂 美
} \\ 静阊女子短期大学
}

大学生の食生活に及ぼす欠食の影響について

\section{Effect of a Habit of Skipping Meals on Dietary Life of College Students}

\author{
Masako Shiraki and Naomi Iwasaki \\ Shizuoka Women's Junior College
}

The nutrient intake, dietary habit and state of health of 3 groups of college students were investigated. Three groups consisted of " 125 female students living with family", "105 female students living on their own" and "60 male students living on their own". We studied how the habit of skipping meals affected their dietary life and state of health.

1) The nutrients, average intakes of which were found to be less than $\mathrm{RDA}$, were $\mathrm{Ca}(75 \sim$ $80 \%$ of $\mathrm{RDA})$ and $\mathrm{Fe}(60 \sim 70 \%$ of $\mathrm{RDA})$ among females and $\mathrm{Ca}(85 \%)$ among males. The intakes by female students of these nutrients per $1,000 \mathrm{kcal}$ were higher than those by male students.

2) Percentage of students who skipped meals habitually (more than one meals skipped during the 3-day period) were as follows. Breakfast was skipped by $11 \%$ of female students living with family, $27 \%$ of female students living on their own, and $53 \%$ of male students living on their own. Lunch was skipped by $8 \%$ of female students living with family, $7 \%$ of female students living on their own, and $12 \%$ of male students living on their own. Supper was skipped by $2 \sim 5 \%$ of male students living on their own.

3) Nutrient intakes were lowered by $10 \sim 25 \%$ due to skipping breakfast and by $35 \%$ due to skipping lunch. This was particularly notable for female students living on their own who skipped breakfast. Quality and quantity of the diets including between-meal snacks of the students who skipped no meals were satisfactory.

4) The irregularity in taking meals and lack of interests in their dietary life were apparent among those who habitually skipped meals.

5) There was no significant relation between the state of health and the habit of skipping meals investigated through presence/absence of subjective symptoms.

Jpn. J. Nutr., 44 ( 5 ) 257 265 (1986)

\section{緒言}

現在, 日本人の栄養状態は平均的には良好で, “日本型食生活”ともいら独自のパターンに対して, 諸外国 から高く評価されるに至った。しかし，多種多様な食品が氾濫し，“飽食の時代”ともよばれる中で，個人や 世代要るいは地域によっては，をだまだ食物摂取上の問題点を残していることが報告されている ${ }^{1) 33}$ 。その中 で, 若い年齢層においては, 食べることがファッション化し, 嗜好本位の食事に偏ったり, 外食や欠食の頻度 が増えるなど，食生活の安易な簡素化が進み，健康へ及ぼす影響が危惧されている。

そこで, 今回, 著者らは特に若い世代の食生活上の問題点として, しばしば指摘される欠食に焦点を当て,

Key words : college students, nutrition survey, skipping meals, dietary habit, health conditions 大学生, 栄養調査, 久食, 食習慣, 健康状態 
ここに, 性別, 住形態別の要因を交差させながら, 久食の有無と栄養摂取の適否, 食習慣および健康状態との 関連性を考察することにした。

\section{調 査 方 法}

\section{1. 調查対象者}

浜松市に所在する短大および大学の女子学生 312 名, 男子学生 87 名のうち, 十分な回答の得られた女子 230 名, 男子 60 名について集計した（有効回収率女子 $75 \%$, 男子 $70 \%$ )。

以上の対象者を住形態別に分けると，女子・自宅生 125名，女子・下宿生 105名となり，男子は全て下宿生 である。年㱓構成は女子の大部分が19〜20歳であり, 男子は20〜23歳であった。

表 1 調査対象者の平均体位

\begin{tabular}{lccr}
\hline 調查対象者 & $\begin{array}{c}\text { 身長 } \\
(\mathrm{cm})\end{array}$ & $\begin{array}{c}\text { 体重 } \\
(\mathrm{kg})\end{array}$ & \multicolumn{1}{c}{$\begin{array}{c}\text { 肥渾度 } \\
(\%)\end{array}$} \\
\hline 女子・自宅生 & $157.2 \pm 4.4$ & $50.4 \pm 4.7$ & $-1.90 \pm 9.14$ \\
女子・下宿生 & $156.8 \pm 5.4$ & $51.1 \pm 3.8$ & $0.68 \pm 9.32$ \\
男子・下宿生 & $172.7 \pm 5.0$ & $61.3 \pm 5.1$ & $-6.34 \pm 6.62$ \\
\hline
\end{tabular}

a) 肥満度 $=\frac{\text { 体重 }-(\text { 身長 }-100) \times 0.9}{(\text { 身長 }-100) \times 0.9} \times 100$

対象者の平均体位は表 1 に示すとおううで，厚生省の60年度推計基準值の同年齢体位（女子：身長 156.6〜 $157.7 \mathrm{~cm}$ ，体重 $51.3 \sim 52.0 \mathrm{~kg}$ ，男子：身長 $170 \mathrm{~cm}$ ，体重 $62.0 \mathrm{~kg}$ ）と比べて，女子はほぼ同程度の体位を示し たが，男子は身長に対し体重がやや下回るやせ型の体型である。

\section{2. 調查期日}

昭和58年の 7 月下旬から 9 月上旬までの夏期休暇中に拈ける連続 3 日間について行った。

\section{3. 調查内容}

3 日間の食物摂取量を秤量法により, 朝, 昼, 夕食別に分けて, その都度, 対象者自身に記録させ，この食 事記録に基づいて 4 訂日本食品成分表により，栄養素量を算定した。ただし，算定に当たり調理上の損失は考 慮していない。なお，記入方法については事前に詳細に指示し，記入もれのないように努めた。

また，上記の食物摂取調查に合わせて，日頃の食習慣および健康状態を図る目的でアンケート調査を行った。 食習慣については 9 項目, 健康状態については身体的症状の11項目を取り上げ, 各項目に対して“はい”, “い いえ”のいずれかの回答を求めた。

\section{調 查 結 果}

\section{1. 性別, 住形態別のグループ平均としてみた場合の食物攝取状況糮查}

女子・自宅生, 女子・下宿生および男子・下宿生の平均栄養素摂取量を表 2 亿示した。な秥, 栄養所要量は 学生の日常の活動状沉よりみて各年齢にお汀る軽い労作に相当するものとした。

摂取状況はどの対象群もカルシウムと鉄を除いて, 他の栄養素は全て所要量にほぼ等しいか, 許容される範 囲で所要量を上回る值となっている。対象群間で異なる点は, 所要量に満たないカルシウムの充足率は女子 75 (自宅生) 80 (下宿生) \%, 男子・下宿生 $85 \%$, 鉄の充足率は女子 60 (下宿生) 70 (自宅生) \%, 男 
表 2 対象別平均栄養素摂取量と充足率

\begin{tabular}{|c|c|c|c|c|c|c|c|c|c|c|c|c|}
\hline & & $\begin{array}{c}\text { エ } \\
\text { ネ } \\
\text { ル } \\
\text { ギ } \\
\text { l } \\
\text { (kcal) }\end{array}$ & $\begin{array}{l}\text { た } \\
\text { ん } \\
\text { 白 } \\
\text { 質 } \\
(\mathrm{g})\end{array}$ & $\begin{array}{c}\text { 質 } \\
(\mathrm{g})\end{array}$ & $\begin{array}{l}\text { 質 } \\
\text { (g) }\end{array}$ & $\begin{array}{l}\text { 維 } \\
(\mathrm{g})\end{array}$ & $\begin{array}{c}\text { カ } \\
\text { ル } \\
\text { シ } \\
\text { ウ } \\
\text { ム } \\
(\mathrm{mg})\end{array}$ & $\begin{array}{c}\text { 鉄 } \\
(\mathrm{mg})\end{array}$ & $\begin{array}{c}\text { ビ } \\
\text { タ } \\
\vdots \\
\text { ン } \\
\mathrm{A} \\
\text { (IU) }\end{array}$ & $\begin{array}{c}\text { ビ } \\
\text { タ } \\
\Xi \\
\ddots \\
B_{1} \\
(\mathrm{mg})\end{array}$ & $\begin{array}{c}\text { ビ } \\
\text { タ } \\
\vdots \\
ソ \\
\mathrm{~B}_{2} \\
(\mathrm{mg})\end{array}$ & $\begin{array}{l}\text { ビ } \\
\text { タ } \\
\vdots \\
\text { ソ } \\
\mathrm{C} \\
(\mathrm{mg})\end{array}$ \\
\hline \multirow{5}{*}{$\begin{array}{l}\text { 女 } \\
\text { 尒 } \\
\text { 自 } \\
\text { 宅 } \\
\text { 生 }\end{array}$} & 摂 取 量 & 1,749 & 62.7 & 57.7 & 236.7 & 3.3 & 445 & 8.4 & 1,985 & 1.20 & 1.09 & 76 \\
\hline & 標 準 偏 差 & 321 & 14.7 & 18.4 & 52.7 & 1.1 & 186 & 2.2 & 1,326 & 0.52 & 0.35 & 34 \\
\hline & 変異係数(\%) & 18 & 23 & 32 & 22 & 33 & 42 & 26 & 67 & 43 & 32 & 45 \\
\hline & 所 要 量 & 1,766 & 63 & $47 \sim 58$ & - & - & 600 & 12 & 1,800 & 0.70 & 0.90 & 50 \\
\hline & 充 足 率(\%) & 99 & 100 & $99 \sim 123$ & 一 & 一 & 74 & 70 & 110 & 171 & 121 & 152 \\
\hline \multirow{5}{*}{$\begin{array}{l}\text { 女 } \\
\text { 尒 } \\
\text { 下 } \\
\text { 宿 } \\
\text { 生 }\end{array}$} & 摂 取 量 & 1,735 & 58.2 & 65.7 & 219.1 & 3.0 & 482 & 7.6 & 2,099 & 0.96 & 1.12 & 79 \\
\hline & 標 準 偏 差 & 388 & 14.8 & 21.4 & 51.0 & 1.1 & 190 & 2.0 & 1,217 & 0.36 & 0.36 & 39 \\
\hline & 変異係数(\%) & 22 & 25 & 33 & 23 & 37 & 39 & 26 & 58 & 38 & 32 & 49 \\
\hline & 所 要 量 & 1,807 & 63 & $48 \sim 58$ & - & - & 600 & 12 & 1,800 & 0.70 & 0.90 & 50 \\
\hline & 充 足 率(\%) & 96 & 921 & $113 \sim 137$ & - & 一 & 80 & 63 & 117 & 37 & 124 & 158 \\
\hline \multirow{5}{*}{$\begin{array}{l}\text { 男 } \\
\text { 子 } \\
\text { 下 } \\
\text { 宿 } \\
\text { 生 }\end{array}$} & 摂 取 量 & 2,476 & 76.4 & 80.9 & 338.6 & 3.3 & 509 & 9.8 & 2,036 & 1. 34 & 1.31 & 72 \\
\hline & 標 準 偏 差 & 564 & 18.6 & 26.7 & 81.6 & 1.2 & 263 & 2.7 & 1,280 & 0.50 & 0.46 & 43 \\
\hline & 変異係数(\%) & 23 & 24 & 33 & 24 & 36 & 52 & 28 & 63 & 37 & 35 & 60 \\
\hline & 所 要 量 & 2,162 & 71 & $50 \sim 62$ & - & - & 600 & 10 & 2,000 & 0.90 & 1.20 & 50 \\
\hline & 充 足 率(\%) & 115 & 108 & $130 \sim 162$ & - & - & 85 & 98 & 102 & 149 & 109 & 144 \\
\hline
\end{tabular}

子・下宿生 $98 \%$ で，女子に比し，男子の蜄取状況のほうがやや良好である。しかし，エネルギー1,000kcal 当 たりの摂取量はカルシウムが女子・自宅生 $254 \mathrm{mg}$ ，女子・下宿生 $278 \mathrm{mg}$ ，男子・下宿生 $206 \mathrm{mg}$ ，鉄はそれぞ れ4. $8 \mathrm{mg} ， 4.4 \mathrm{mg} ， 4.0 \mathrm{mg}$ となり，いずれも男子・下宿生よりも女子の自宅生および下宿生のほうが多い。

また，たん白質と脂質の摂取については，全体的にたん白質に比べて脂質の充足率が高いが，この傾向は自 宅生よりも下宿生に，その中でも男子・下宿生において顕著である。

ビタミン類の撕取量は 3 群とも全て所要量を上回っているが，これに調理上の損失 (V. A $20 \%$ ，V. $\mathrm{B}_{1} 30 \%$, V. $\mathrm{B}_{2} 25 \%$ ，V. C $50 \%$ ）を加味すれば，ビタミン $\mathrm{B}_{1}$ を除いて他のビタミン類は所要量を下回ることになる。 变異係数は栄養素別では，お拈むねどタミン類の值が大きい。3 群間の比較では男子・下宿生の值がやや大 きいものの対象群の間に大きな差異はみられない。

次に食品群別摄取量をみると（図 1), 男女別で摂取量に大きな差がある食品群は米，肉，緑黄色野菜，果 実, 嗜好飲料および調理加工品類である。このうち米, 肉, 嗜好飲料, 調理加工品は男子の摂取量が女子をか なり上回り, 緑黄色野菜, 果穾は逆に女子に多い。女子の 2 群については摂取量の有意差検定を行った。有意 差が認められたのは, 米, パン, 魚, 乳・乳製品, 喍好飲料で, これらの食品群は住形態の違いが摄取量に影 響している。

\section{2. 欠食の有無と摂取栄養量の関係}

図 2 は，先の対象者のエネルギ一充足状況を個人別にみたものである。これによると，所要量に対し $\pm 10 \%$ 未満の範囲に含まれる者は女子で35（下宿生）～40（自宅生）\%，男子で30\%を占めるものの，一方で，所要 量を10\%以上下回る者が合わせて女子で35（自宅生）～40（下宿生）％，男子で17\%いる。このような低摂取 エネルギーの原因として，欠食の問題が考兄られるので，対象者の欠食状況を調べ，続いて欠食と栄養摂取上 


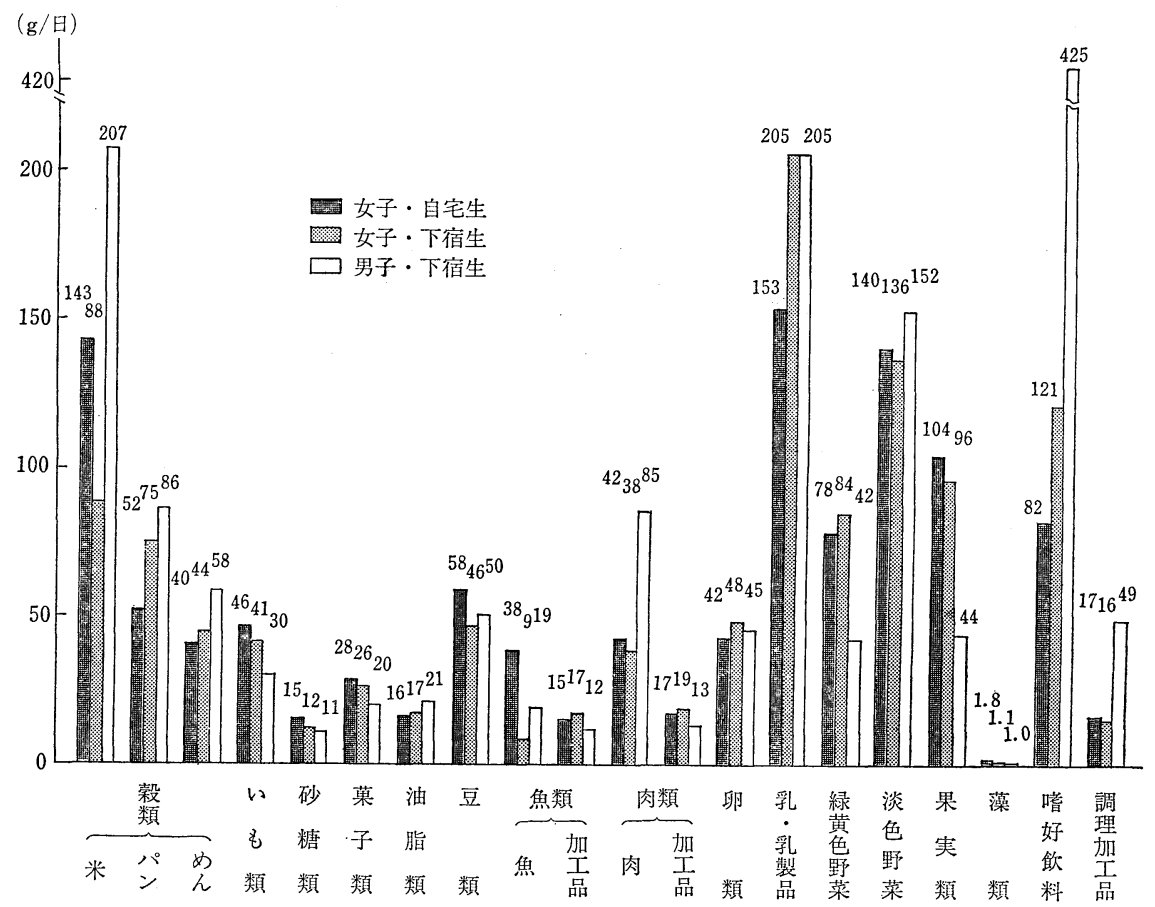

図 1 対象別食品群別摂取量

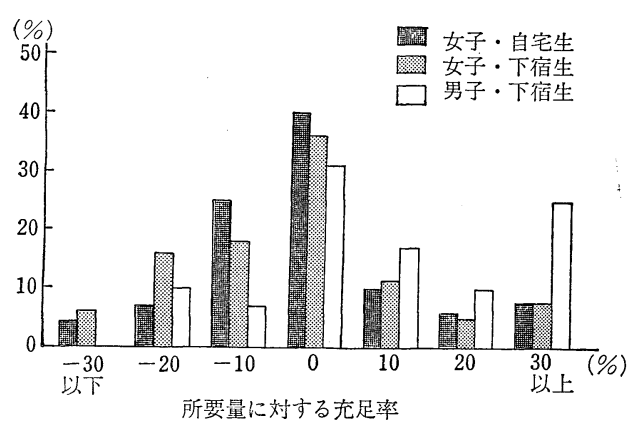

図 2 摂取エネルギーの充足状況 0 は摂取量が所要量の $\pm 10 \%$ 末満の区分

の不均衡との関連性を観察した。

表 3 に示すごとく，3 日間のうち朝食を 1 回以上 欠食した人の割合は女子・自宅生 $11 \%$,女子・下宿 生 $27 \%$, 男子・下宿生 $52 \%$ で, 男子・下宿生の欠 食率の高いのが目立つ。しかも, 男子の欠食者のう

表 3 欠食状況 $(\%)$

\begin{tabular}{|c|c|c|c|c|}
\hline $\begin{array}{l}\text { 対 } \\
\text { 象 }\end{array}$ & $\begin{array}{l}3 \text { 日間の } \\
\text { 欠食回数 }\end{array}$ & 朝 & 昼 & 夕 \\
\hline \multirow{5}{*}{$\begin{array}{l}\text { 女 } \\
\text { 子 } \\
\text { 自 } \\
\text { 宅 } \\
\text { 生 }\end{array}$} & なし & 89 & 92 & 98 \\
\hline & あり & 11 & 8 & 2 \\
\hline & 1 回 & 7 & 6 & 2 \\
\hline & 2 回 & 3 & 2 & 0 \\
\hline & 3 回 & 1 & 0 & 0 \\
\hline \multirow{5}{*}{$\begin{array}{l}\text { 女子 } \\
\text { 古 } \\
\text { 宿 } \\
\text { 生 }\end{array}$} & なし & 73 & 93 & 97 \\
\hline & 西り & 27 & 7 & 3 \\
\hline & 1 回 & 18 & 6 & 3 \\
\hline & 2 回 & 8 & 1 & 0 \\
\hline & 3 回 & 2 & 0 & 0 \\
\hline \multirow{5}{*}{$\begin{array}{l}\text { 男 } \\
\text { 子 } \\
\text { 市 } \\
\text { 宿 } \\
\text { 生 }\end{array}$} & なし & 48 & 88 & 95 \\
\hline & あり & 52 & 12 & 5 \\
\hline & 1 回 & 22 & 7 & 5 \\
\hline & 2 回 & 18 & 2 & 0 \\
\hline & 3 回 & 12 & 3 & 0 \\
\hline
\end{tabular}

ち $18 \%$ 日間で 2 回欠食, また $12 \%$ 回とも欠食しており, これら合わせて $30 \%$ 人は朝食をとらないこ とがほぼ常習化しているものと思われる。昼食については，1回以上の欠食者は女子・自宅生 $8 \%$ ，女子・下 宿生 $7 \%$, 男子・下宿生 $12 \%$ である。夕食の 1 回以上の欠食者は女子・自宅生 $2 \%$, 女子・下宿生 $3 \%$, 男子・ 下宿生 $5 \%$ で，3 群とも夕食の欠食は予想どおり低率であるが，昼食は10\%程度の欠食率であった。ちなみに， 
昭和58年度国民栄養調査の $20 ２ 4$ 歳年軨の欠食率 ( 3 日間のらち 1 回以上の欠食回数) をみると, 朝食 が女 $21.4 \%$, 男 $32.0 \%$, 昼食は女 $6.4 \%$, 男 $6.3 \%$, 夕食は女 $3.2 \%$, 男 $4 \%$ である。以上の結果と比較 して本調查は概して男子の欠食率が高い。しかし， これについては両者が同じ年齢層といっても, 今回 の対象者が男子の下宿生であることの特徴が現れた 結果と思われる。

欠食の主な理由は, “時間がない”, “作るのがめ んぞう”, “食欲がない”などで, “美容のため”, “や せるため”のようにはっさりした目的をもって欠食 している者は少なかった。このほか, 男子・下宿生 は“金がない”と回答した者もいた。

図 3 は, 対象群の 3 日間の食事を欠食の有無によ り, “3 食あり”, “朝・年食”, “昼・覀食” の別に分 け，各グループごとにェネルギー，たん白質，脂質 および糖質について 1 人 1 日当たりの平均摂取量と 標準偏差を求めたものである。な扐, 夕食は久食者 が少ないため今回の分析では “夕・欠食”群は省略 した。

対象群ごとに全体の平均值と, “ 3 食あり”, “朝・

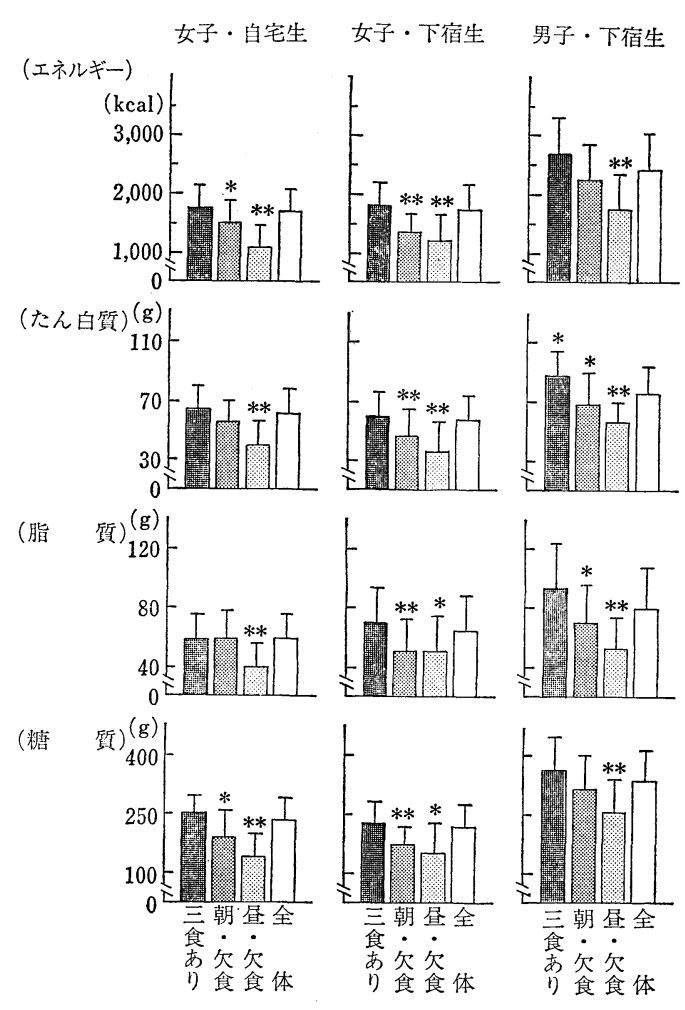

図 3 欠食の有無と栄養素摂取量 (平均値と 䅺準偏差) の関係

* $p<0.05, * * \quad p<0.01$ で, 全体との間に 有意差あり

欠食”, “昼・欠食”別の平均値を比較すると, いずれの対象群においても欠食により全ての栄養素量が低下す

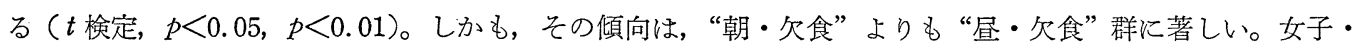
自宅生の “朝・欠食” の場合, 脂質を除いた他の栄養素が全体平均に比べて10２0\%減少し，“昼・欠食”で

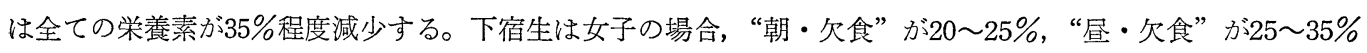
減少，男子の場合は “朝・欠食” が $10 \%$ 弱, “昼・欠食” が $30 \%$ 減少する。以上のように, “昼・欠食”による 摂取量の低下は 3 群とも $30 \%$ 程度であるが，“朝・欠食” は女子・下宿生が 20 ～ $25 \%$ と最も大きい。しかも， 全ての栄養素の低下に有意差が認められる。これは，女子・自宅生と男子・下宿生は朝の食事が㡺および夕食 に比べて簡単なものであるのに対し, 女子・下宿生は朝, 昼, 夕食の食事内容に差がなく, 朝食といっても質, 量とも比較的整った内容であることを示し，このため，女子・下宿生の“朝・欠食” はかなりの摂取量の低下 を招くことになる。

続いて，朝また昼の欠食が夕食や間食に影響を与えているか否かを調べた。

まず, 夕食でとるエネルギーを計算すると，女子・自宅生の場合，“ 3 食あり” $645 \mathrm{kcal}$ (“ 3 食市り”群の 1 日平均摂取量の $36 \%$ ), “朝・次食” $605 \mathrm{kcal}(40 \%)$, “昼・次食” $602 \mathrm{kcal}(54 \%)$, 女子・下宿生の場合,

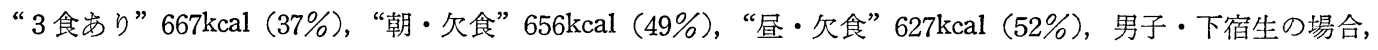
“3 食あり” 1,018kcal (38\%), “朝・欠食” 1,081kcal (47\%), “㡺・欠食” $994 \mathrm{kcal}(56 \%)$ であ。この結 果をみると，男女間で差があるのは当然としても，“3 食あり”，“朝・欠食”, “昼・欠食”の間には夕食時の 
表 4 夕食の料理数と食品数

\begin{tabular}{|c|c|c|c|c|c|}
\hline 対象 & 欠食の有無 & 料理数 & 食品数 & 相関係数 & 回帰係数 \\
\hline \multirow{3}{*}{$\begin{array}{l}\text { 女臬 } \\
\text { ·生 }\end{array}$} & 朝-欠食 & $3.2 \pm 1.5$ & $9.2 \pm 3.1$ & $0.469^{*}$ & 0.958 \\
\hline & 昼-欠食 & $3.1 \pm 0.9$ & $8.3 \pm 3.4$ & 0.254 & 0.972 \\
\hline & 3 食あり & $3.5 \pm 0.8$ & $9.7 \pm 2.3$ & $0.388^{* *}$ & 1.071 \\
\hline \multirow{3}{*}{$\begin{array}{l}\text { 女下 } \\
\text { 子宿 } \\
\text { - 生 }\end{array}$} & 朝-欠食 & $3.1 \pm 1.0$ & $8.1 \pm 2.1$ & $0.495^{* *}$ & 1.084 \\
\hline & 昼- 欠食 & $2.9 \pm 1.4$ & $7.3 \pm 4.4$ & 0.473 & 1.444 \\
\hline & 3 食あり & $2.9 \pm 0.8$ & $7.8 \pm 2.0$ & $0.462^{* *}$ & 1.168 \\
\hline \multirow{3}{*}{$\begin{array}{l}\text { 男下 } \\
\text { - 宿 } \\
\text { 生 }\end{array}$} & 朝-欠食 & $3.3 \pm 1.4$ & $8.0 \pm 3.8$ & $0.597^{* *}$ & 1.638 \\
\hline & 昼-欠食 & $3.1 \pm 1.4$ & $11.5 \pm 5.5$ & $0.713^{* *}$ & 2.727 \\
\hline & 3 食あり & $3.8 \pm 1.1$ & $9.6 \pm 2.6$ & $0.792^{* *}$ & 1.824 \\
\hline
\end{tabular}

* $p<0.05, \quad * * \quad p<0.01$

エネルギー量に大きな差がみられない。すなわち，朝あるいは昼を欠食したから，その分夕食で多食するとい らのではなく，むしろ“3 食あり”群の流らがたくさん食べている傾向さ光見受けられる。

次に, 夕食の食事内容を料理数と使用食品数からみると（表 4 ）, 全対象群の料理数の平均値は $2.9 \sim 3.8$, 食品数の平均値は7.0 11.5の範囲にあり, 女子の “昼・欠食” 群を除いて料理数と食品数の間に有意の正の 相関が恐められた。平均料理数はいずれの群もほぼ 3 品で差はないが, 食品数は男子・下宿生群が $1 〜 2$ 種類 多く, 逆に女子・下宿生群がやや少ない。男子・下宿生の食品数が多いのは, 本調查に和ける男子・下宿生の 夕食時の外食率が $40 \%$ と高く, 自炊に比べて飲食店での食事は 1 品当たりの食品数が多いためである。対象群

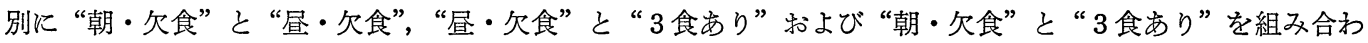
せて, 料理数と食品数について相関係数の差の検定 ${ }^{4)}$ および回帰係数の差の検定 ${ }^{5)}$ を行ったが，いずれの組み 合わせにおいても有意差は認められなかった。

3 回の食事以外の間食でとるェネルギー量は，女子・自宅生の“3 食あり” $151 \mathrm{kcal}$ ，“朝・稘” $218 \mathrm{kcal}$,

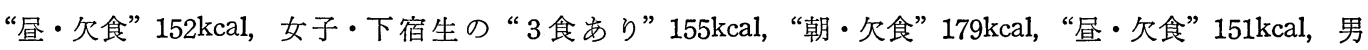

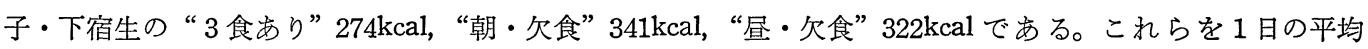

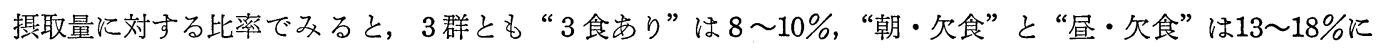
相当し，次食群のほうが間食の占める比率が高い。

以上のように, 夕食時のエネルギー量や料理数, 食品数は朝あるいは昼の欠食の有無に関係なく, どの対象 群も同一の傾向を示すことから，欠食群は残り 2 回の食事の内容を充実させる方向へ気を配るのではなく, 菓 子類を主とする間食で補充しょらとする食習性をもっているものと思われる。

\section{3. 対象別にみた食習慣}

前述の 3 対象群と欠食の有無の 2 つ要因と食習慣の関連について観察し, 表 5 の結果を得た。“食事が 不規則”，“間食が多い”，“食品の組み合わせを気にしない”は全対象者の $30 \%$ 以が “はい”之回答した項 目である。回答の内容々 2 つ要因の相互の関係を $\chi^{2}$ 検定法を用いて分析すると, “間食が多い”は女子に $(p<0.01 ， p<0.05) ， “$ 食品の組み合わせを気にしない”は男子に多く $(p<0.01) ，$ を，“食事が不規則”， “欠食が多い”は男女の下宿生に多い $(p<0.01, p<0.05)$ など性拉よび住形態が異なることによる食習慣の 違いが顕著に現れている。

欠食の有無との関連では, “食事が不規則”, “欠食が多い”, “食品の組み合わせを気にしない”の項目につ 
表 5 対象別にみた食習慣

\begin{tabular}{|c|c|c|c|c|c|c|c|c|}
\hline & & $\begin{array}{l}\text { 女子 } \\
\text { 自宅生 }\end{array}$ & 女子· & 男子 & $\begin{array}{l}3 \text { 群間 } \\
\text { の㭘定 }\end{array}$ & 欠食a) & 非欠食 & $\begin{array}{l}2 \text { 群間 } \\
\text { の検定 }\end{array}$ \\
\hline 1. & 食事が不規則 & $32 * * 1,2$ & $59^{* * 1}$ & $68^{* * 2}$ & ** & 67 & 35 & $* *$ \\
\hline 2. & 好き嫌いが多い & 17 & 12 & 8 & - & 17 & 10 & - \\
\hline 3. & 間食が多い & $49^{* 1}$ & $66^{* * 3}$ & $30 * 1, * * 3$ & $* *$ & 48 & 50 & - \\
\hline 4. & 欠食が多い & $34^{* 2, * * 4}$ & $59 * 2$ & $78^{* * 4}$ & $* *$ & 84 & 28 & $* *$ \\
\hline 5. & 食品の組み合わせを気にしない & $30^{* * 5}$ & $32^{* * 6}$ & $70^{* * 5,6}$ & $* *$ & 56 & 28 & $* *$ \\
\hline & 保健薬，栄養剤を常用する & 3 & 0 & 0 & - & 0 & 3 & - \\
\hline 7. & 睡眠薬を常用する & 0 & 0 & 0 & - & 0 & 0 & - \\
\hline & 契煙 & $0^{* * 7}$ & $2^{* * 8}$ & $46^{* * 7,8}$ & $* *$ & 19 & 8 & $*$ \\
\hline & 飲酒 & $0^{* * 9}$ & $0^{* * 10}$ & $38^{* * 9,10}$ & $* *$ & 19 & 3 & $* *$ \\
\hline
\end{tabular}

a） 3 日間の食事のらち 1 回以上欠食した者

* p<0.05, ** $p<0.01, \quad$ - 有意差なし

表 6 対象別にみた健康状態

$(\%)$

\begin{tabular}{|c|c|c|c|c|c|c|c|c|}
\hline & & $\begin{array}{l}\text { 女子 } \\
\text { 自宅生 }\end{array}$ & $\begin{array}{l}\text { 女子・宿生 } \\
\text { 它 }\end{array}$ & $\begin{array}{l}\text { 男子 } \\
\text { 下宿生 }\end{array}$ & $\begin{array}{l}3 \text { 群間 } \\
\text { の検定 }\end{array}$ & 欠食 ${ }^{2)}$ & 非欠食 & $\begin{array}{l}2 \text { 群間 } \\
\text { の検定 }\end{array}$ \\
\hline 1. & 眠れない & $0^{* * 1}$ & $0^{* * 2}$ & $14^{* * 1,2}$ & $* *$ & 6 & 1 & - \\
\hline 2. & 疲れやすい & 45 & 51 & 30 & - & 38 & 46 & - \\
\hline 3. & いらいらする & 15 & 17 & 22 & - & 22 & 14 & - \\
\hline 4. & かぜをひきやすい & 14 & 22 & 22 & - & 19 & 18 & - \\
\hline 5 . & 体の痛み & 9 & 12 & 14 & - & 8 & 14 & - \\
\hline 6 . & 肩こり & 45 & 32 & 24 & - & 37 & 35 & - \\
\hline 7. & 食欲がない & 11 & 5 & 11 & - & 13 & 6 & - \\
\hline 8. & 便通不規則 & $49^{* * 3}$ & $49^{* * 4}$ & $19^{* * 3,4}$ & $* *$ & 40 & 43 & - \\
\hline 9. & 下峲 & 26 & 17 & 19 & - & 24 & 20 & - \\
\hline 10. & 便秘しやすい & $40^{* * 5}$ & $32^{* 1}$ & $11^{* 1, * * 5}$ & * & 22 & 36 & - \\
\hline 11. & 立ちくらみ & $52^{* 2}$ & 49 & $27^{* 2}$ & $*$ & 40 & 49 & - \\
\hline
\end{tabular}

a） 3 日間の食事のうち 1 回以上欠食した人

* $p<0.05, \quad * * \quad p<0.01, \quad$ - 有意差なし

いて, 欠食群の “はい”の回答頻度が有意に高い。本調査では, 3 日間のらち 1 回以上欠食した者は全て欠食 群として扱ったが，以上の結果から考えると，欠食群に属する者は今回の調査期間中に偶然 $1 \sim 2$ 回の欠食が 含まれたというのではなく，次食が習慣的に存在することが示された。猰煙や飲酒は男子にのみみられる習慣 であり，中でも欠食群に有意洺い。

\section{4. 対象別にみた健康状態}

先の $2 つ の$ 要因と健康状態との関連性を観察した。

表 6 亿あげた11項目の身体的症候に対し，自覚的訴兄の有無を尋齐，訴えのある者の割合（\%）を対象別に 示した。全項目に対する訴光数の平均値之標準偏差は，女子・自宅生 $3.1 \pm 2.1$, 女子・下宿生 $2.9 \pm 1.8$, 男 子・下宿生 $2.1 \pm 2.0$ である。また，5つ以上の項目について訴齐あ゙あ者の割合は，それぞれ $15 \% ， 22 \% ， 14$

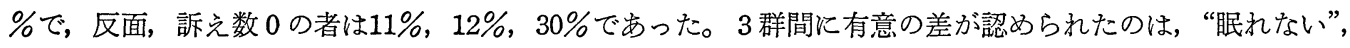
“便通が不規則”，“便秘しやすい”および “立ちくらみ”の4項目である。このうち，“眠れない”と答觉た者 は男子に多く $(p<0.01)$, “便秘しやすい”, “便通が不規則” は女子に多い $(p<0.01, p<0.05)$ 。さらに, 
“立ちくらみ”は女子の自宅生に多かった $(p<0.05)$ 。以上のよらに, 訴光数および訴光の内容からみると, 男子に比べて女子の注うが相対的に訴光の頻度が高く, また女子に多くみられるこれらの自覚症状は他の調查 結果でも示されるごとく，若い女性にとって特徴的な現象である。

欠食の有無との関連では, 11 のずれの項目においても2 群間に有意の差がみられず, 本調查では欠食群で あっても身体的にこれといった自覚的症状は認められなかった。

\section{考察}

今回の調査は，女子・自宅生，女子・下宿生就よび男子・下宿生の対象集団の平均的な栄養摂取状況の実態 を把握し, さらに，20歳代という年龄層をた下宿生を含むという対象群の特性を考えて，特に欠食の問題を取 り上げ，欠食の有無と栄養摄取状況，食習慣および健康状態との関連性を観察することを目的とするものであ る。

既述の結果から考察すると, 上記の 3 対象群の平均的な栄養素抏取は, いずれの対象群もカルシウムと銑を

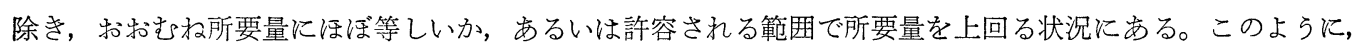
女子・自宅生はともかく, 摂取状況が懸念された男女の下宿生に重大な栄養摂取の不均衡がみられなかったこ とは一応評価できることである。しかし, 各栄養素の摂取量の間には正の相関がある6) といわれているが, 本 調査では他の栄養素の充足度が高いにもかかわらず, 先のカルシウムと鉄の摂取不足が著しいこと, また, 男 女の下宿生に共通することとして，たん白質に比べて脂質の摂取量が多く，130１50\%の充足率に達している こと, さらに, 男子・下宿生は撖取量の個人差が大きいことなどが健康への影響を考えると, 今後, この面へ の配慮が強く望まれるところである。

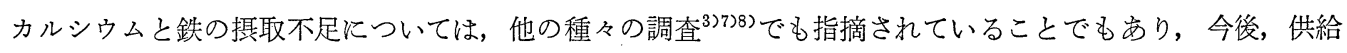
源としての食品構成や献立内容からの検討を加え, カルシウムと鉄の摂取状沉をもら少し詳しく研究したいと 考えている。

先に，男子・下宿生の摂取状況が予想した以上に良好であった旨報告したが，男子・下宿生の場合，1日の 食事のらち 1 回外食している者 37\%，2回外食している者 $31 \%$ と外食の頻度が極めて高いことを考兄ると， 良好とはい光外食に依存したこのような食事内容には問題が残ることを考慮する必要がある。

最近の国民栄養調査によれば，男女とも20歳代の若い世代の欠食率が高いことが指摘されているが，本調査 の欠食状況については既述のと到りで，朝食を常習的に欠食する者は女子・下宿生で $10 \%$, 男子・下宿生で30 \%を占める。欠食による摂取量の低下は, 朝食で10～25\%, 昼食で $35 \%$ に及び, 充足率は各々 $85 \%, 65 \%$ 程度 に下がる。中でも女子・下宿生の “朝・食”による摂取量の低下が目立つが，これは見方を変えれば他の 2 群に比べて, 女子・下宿生の朝の食事内容が質, 量の面で優れていることを示すものである。朝あるいは昼の 欠食者は欠食を意識して，その分夕食や間食で多く摄取するのではないかと考えたが，“3 食めり”群と異な る摂取傾向は認められず, むしろ“3 食あり”群のほうが 3 回の食事や間食を含めて食事内容が充実しており， 食べることへの意欲が感じられる。

今回の健康状況調査では, 欠食の有無と身体的症状との関連では有意性が認められず, 久食群でも今のとこ ろ身体的異常は現れていない。しかし, 欠食者の食習慣のうち, “食事が不規則”, “欠食が多い”, “食品の組 み合わせを気にしない”は, 非久食群に比し, “はい”の回答が有意に高い項目である。また，欠食の主な理 由が, “時間がない”, “作るのがめんどう”, “食欲がない”などであることを考台合わせると, 欠食群の不規 
則な食事は日常的にみられることであり, 食事に対する関心が極めて乏しいように思う。一方, 栄養拄取のあ り方と健康状態との関連性について, 貧血と朝食抜きやェネルギー摂取量の間に有意性を認めた報告2)もみら れる。欠食が改善されないで, 栄養摂取の充足度が低い食生活が慢性化するならば, これが原因して健康を害 する恐れが生じてくる。したがって, 若い年㱓層の健康維持のために, まず欠食をなくすところから食生活の 見直しを図る指導を推めたいと考学る。

\section{要約}

女子・自宅生 125 名, 女子・下宿生 105 名就よび男子・下宿生 60 名を対象に, 食物摂取状況調查と食習慣㧍 よび健康状態を問う調査を行い，対象別に欠食の有無が食生活や健康状態に及ぼす影響を観察した。

1）所要量を満たしていない栄養素は, 女子はカルシウム（75～80\%), 鉄（60～70\%）で，男子はカルシ ウム $(85 \%)$ である。この 2 つの栄養素の $1,000 \mathrm{kcal}$ 当たりの摂取量は, 女子の注うが男子よりも多い。

2）欠食者 ( 3 日間のうち 1 回以上欠食) の割合は, 朝食は女子・自宅生 $11 \%$, 女子・下宿生 $27 \%$, 男子・ 下宿生 $53 \%$ ，昼食は女子・自宅生 $8 \%$ ，女子・下宿生 $7 \%$ ，男子・下宿生 $12 \%$ ，夕食は 2 ～ $5 \%$ であった。

3） 欠食による栄養素摂取量の低下は, 朝食で10～25\%, 昼食で35\%に及び，中でも女子・下宿生は朝食を 欠食した時の摂取量の低下が大きい。“3 食めり”群は, 食事および間食を含めて, 質と量の面で食事の内容 が充実している。

4）欠食者の食習慣や欠食理由から，欠食者の不規則な食事は日常的にみられることであり，食事に対する 関心が極めて乏しいことが指摘された。

5）自覚症状の有無によって調查した健康状態と欠食の有無との間には，有意の関係は見出せなかった。

\section{文献}

1）山上雅子, 豊川裕之, 他：栄養之食糧, 35, 27〜37（1982）

2）石垣志津子：栄養学雑誌, 37, 139〜146（1979）

3）山中千代子, 相田貞子 : 栄養学雑誌，40，247～258（1982）

4）水野哲夫：統計の基礎と実際，pp. 159 160（1981）光生館

5）遠藤健児, 鍋谷清治訳 : 研究者のための統計的方法, pp. 110～111（1979）森北出版

6）豊川裕之：生活の中の栄養学, p. 89 (1983) 大修館書店

7）前川當子, 八倉巻和子, 他：栄養学雑誌, 35, 307 314（1977）

8）池田順子, 浅野弘明, 他：栄養学雑誌, 41, 103 116（1983）

（受付：昭和61年 4 月 3 日） 